\title{
Black Cumin (Nigella sativa) and Its Active Constituent, Thymoquinone: An Overview on the Analgesic and Anti-inflammatory Effects
}

Authors

Affiliations
Bahareh Amin ${ }^{1}$, Hossein Hosseinzadeh ${ }^{2}$

${ }^{1}$ Department of Pharmacology and Physiology, School of Medicine, Sabzevar University of Medical Sciences, Sabzevar, Iran 2 Pharmaceutical Research Center, Department of Pharmacodynamics and Toxicology, School of Pharmacy, Mashhad University of Medical Sciences, Mashhad, Iran

\author{
Key words \\ - Nigella sativa \\ - Ranunculaceae \\ - thymoquinone \\ - analgesia activity \\ - anti-inflammatory effect
}

received Nov. 22, 2014

revised June 29, 2015

accepted July 16, 2015

Bibliography

DOI http://dx.doi.org/

$10.1055 / \mathrm{s}-0035-1557838$

Published online September 14, 2015

Planta Med 2016; 82: 8-16

(c) Georg Thieme Verlag KG

Stuttgart · New York .

ISSN 0032-0943

\section{Correspondence}

Prof. Dr. Hossein Hosseinzadeh

Pharmaceutical Research Center

School of Pharmacy

Mashhad University of Medical

Sciences

Department of Pharmaco-

dynamics and Toxicology

1365-91775 Mashhad, I. R.

Iran

Phone: + 985138819042

Fax: + 985138823251

hosseinzadehh@mums.ac.ir

\section{Abstract \\ $\nabla$}

For many centuries, seeds of Nigella sativa (black cumin), a dicotyledon of the Ranunculaceae family, have been used as a seasoning spice and food additive in the Middle East and Mediterranean areas. Traditionally, the plant is used for asthma, hypertension, diabetes, inflammation, cough, bronchitis, headache, eczema, fever, dizziness, and gastrointestinal disturbances. The literature regarding the biological activities of seeds of this plant is extensive, citing bronchodilative, anti-inflammatory, antinociceptive, antibacterial, hypotensive, hypolipidemic, cytotoxic, antidiabetic, and hepatoprotective effects. The active ingredients of $N$. sativa are mainly concentrated in the fixed or essential oil of seeds, which are responsible for most health benefits. This review will pro-

\section{Introduction}

The use of medicinal plants in various ailments dates back to the earliest years of man's evolution [1]. Nigella sativa L. (Ranunculaceae) is an indigenous herbaceous plant native to Southwest Asia including Iran, India, and Pakistan. The plant grows to a maximum height of about $40-70 \mathrm{~cm}$ and has finely divided foliage and pale blue and white flowers. From the fruit capsules, many small caraway-type black seeds are produced (length: 2.5 to $3.5 \mathrm{~mm}$ and width: 1.5 to $2 \mathrm{~mm}$ ). In different languages the plant is known by various names, e.g., black cumin, black seed, blackcaraway (English), Habbah Al-Sauda, seed of blessing (Arabic), chernushka (Russian), çörek otu (Turkish), and Cyah-daneh in Persian. For thousands of years, the seeds of this plant have been used as a spice and additive in bread, cookies, and other dishes in many Asian and Eastern countries [2]. Therapeutic benefits of black cumin and vide all updated reported activities of this plant with an emphasis on the antinociceptive and anti-inflammatory effects. Results of various studies have demonstrated that the oil, extracts, and their active ingredients, in particular, thymoquinone, possess antinociceptive and anti-inflammatory effects, supporting the common folk perception of N. Sativa as a potent analgesic and antiinflammatory agent. Many protective properties are attributed to reproducible radical scavenging activity as well as an interaction with numerous molecular targets involved in inflammation, including proinflammatory enzymes and cytokines. However, there is a need for further investigations to find out the precise mechanisms responsible for the antinociceptive and anti-inflammatory effects of this plant and its active constituents.

its active ingredients have been demonstrated in many investigations [3-5].

\section{Chemical Composition}

$\nabla$

$N$. sativa seeds contain various compositions including moisture, oil, proteins (eight of the nine essential amino acids), carbohydrates, vitamins, and minerals $[6,7]$. The percentage of ingredients varies with the geographic distribution, time of harvest, and cultivation methods [8].

In a study by Cheikh-Rouhou et al. comparing Tunisian and Iranian varieties for their quality attributes, the Tunisian variety contained 8.65, $28.48,26.7,4.86$, and $40.0 \%$ of moisture, oil, proteins, ash, and carbohydrates, respectively, while analysis of the Iranian variety showed 4.08 , $40.35,22.6,4.41$, and $32.7 \%$ of the respective attributes [9].

Black cumin seed is composed of fixed (stable) and essential (volatile) oil responsible for many 
Table 1 The general chemical composition of $N$. sativa seeds $[6-8,11-17]$.

\begin{tabular}{|c|c|c|c|}
\hline Constituents & & Chemical composition & $\%$ Range (w/w) \\
\hline \multirow[t]{2}{*}{ Oil } & Fixed oil & $\begin{array}{l}\text { Linoleic acid (Omega-6), Oleic acid, Palmitoleic acid Linolenic acid (Omega-3), Myristoleic acid, Diho- } \\
\text { molionolenic acid, Stearic acid, Eicosadienoic acid, Myristic acid, Arachidic acid, Behanic acid, Sterols } \\
\text { ( } \beta \text {-sitosterol, avenasterol, stigmasterol, campesterol and lanosterol), Tocopherols ( } \alpha, \beta \text {, and } \gamma \text { ) Thymo- } \\
\text { quinone, Retinol (vitamin A), Carotenoids ( } \beta \text {-carotene) }\end{array}$ & $22-38 \%$ \\
\hline & Volatile oil & $\begin{array}{l}\text { Thymoquinone, } p \text {-Cymene, Carvacol, } \alpha \text {-Pinene, } \beta \text {-Pinene, Longifolene, t-Anethole Thymol, Thymo- } \\
\text { hydroquinone, Dithymoquinone (nigellone) }\end{array}$ & $0.40-1.50 \%$ \\
\hline Protein & & $\begin{array}{l}\text { Glutamic acid, Arginine, Aspartic acid, Leucine, Glycine, Valine, Lysine, Threonine, Phenylalanine Iso- } \\
\text { leucine, Histidine, Methionine }\end{array}$ & $20.8-31.2 \%$ \\
\hline Carbohydrate & & Glucose, Rhamnose, Xylose, Arabinose & $24.9-40 \%$ \\
\hline Minerals & & Calcium, Phosphorus, Iron, Potassium, Sodium, Zinc, Magnesium, Manganese, Copper, Selenium & $3.7-7 \%$ \\
\hline Saponins & & $\alpha$-Hederin (melanthin), Hederagenin (melanthigenin) & $0.013 \%$ \\
\hline Alkaloids & & Nigelicine, Nigellimine, Nigellidine & $0.01 \%$ \\
\hline Other Vitamins & & Vitamin A, Thiamin, Riboflavin, Pyridoxine, Niacin, Folacin, Vitamin C & $1-4 \%$ \\
\hline
\end{tabular}<smiles>CC(C)C1=CC=C(Cl)CC1</smiles>

p-Cymene<smiles>CC(C)C1=CC(=O)[C@@]2(C)C(C1=O)[C@]1(C)C(C(C)C)=CC(C(C)C)C(=O)C21</smiles>

Fig. 1 Chemical structure of the active ingredients of oil of $N$. sativa L. seeds.<smiles>CC1=CC(=O)C(C(C)C)=CC1=O</smiles>

Thymoquinone (TQ)<smiles>CC(C)c1cc(O)c(Cl)cc1O</smiles>

Thymohydroquinone (THQ)<smiles>CC1=CC(O)=C(C(C)C)CC1</smiles>

Thymol (THY) beneficial effects attributed to $N$. sativa. Fixed oil contains appreciable quantities of unsaturated fatty acids (linoleic, oleic, and inolenic acids) as well as saturated fatty acids in minor amounts (arachidonic and eicosenoic acids). Dihomo- $\gamma$-lionoleic acid is a powerful antioxidant, which exists in the fixed oil of seeds [3, 10]. Besides the fatty acid profile, it also consists of considerable quantities of vitamin $\mathrm{E}$ (tocopherol $\alpha, \beta$, and $\gamma$ ), retinol (vitamin A), carotenoids ( $\beta$-carotene), and thymoquinone (2-isopropyl-5methyl-1,4-benzoquinone). Fat-soluble vitamins comprise more than $0.2 \%$ of the total oil content $[11,12]$.

Other ingredients of $N$. sativa include minerals such as potassium, phosphorus, calcium, and iron, in greater quantities, as well as zinc, magnesium, manganese, selenium, and copper in fewer amounts. Alkaloids such as nigellimine, nigellidine, and nigellicine are also present in trace amounts [11-13]. Black cumin has been known to contain considerable quantities of phytosterols including $\beta$-sitosterol, avenasterol, stigmasterol, campesterol, and lanosterol [14-16].

Moreover, essential oil extracted from black cumin is of functional importance because of its rich volatiles, such as $18.4-24 \%$ thymoquinone (TQ), $46 \%$ monoterpenes including $p$-cymene, $\alpha$ - pinene, thymol (THY), dithymoquinone (DTQ nigellone), and thymohydroquinone (THQ) [17-19]. The general chemical composition of $N$. sativa seeds has been presented in O Table 1 [6$8,10-17]$. Photodimerization of thymoquinone as a consequence of exposure to sunlight during separation and extraction of the quinones from the seed produces dithymoquinone. Among the components isolated from the volatile oil of $N$. sativa, TQ has been demonstrated to be the principal active ingredient $[11,20]$. The chemical structure of main ingredients of $N$. sativa oil including thymoquinone, dithymquinone, thymohydroquinone, $p$ cymene, and thymol is shown in $\boldsymbol{O}$ Fig. 1.

\section{Traditional Uses of Nigella sativa $\nabla$}

Traditional uses of this amazing herb originate from the ancient Egyptians, Greeks, and Romans. Black seed is referred to by the Islamic prophet Mohammed as having healing powers for every disease except death. $N$. sativa has been advocated by Ibn Sina (Avicenna), the most famous physician and philosopher of the Islamic world, as the body's energizing compound and as a remedy 
for fever, headaches, toothaches, and common colds. It was also recommended as a soothing agent for skin disorders, wounds, and external irritations [21]. According to the Holy Bible, black seed is described as the melanthion by Hippocrates and Dioscorides and as the Gith by Pliny [22].

In folklore medicine, the seeds and oil of $N$. sativa have been frequently prescribed as a natural remedy for a diverse range of diseases, such as, fever, cough, nasal congestion, bronchitis, asthma, dyspnea, hypertension, diabetes, inflammation, milk production, eczema, dizziness, and gastrointestinal disturbances. Its use in pain conditions such as headaches, toothaches, and back pain has also been recommended $[23,24]$.

\section{Pharmacological Studies on the Biological Activities $\nabla$}

$N$. sativa and its main active constituent TQ have been attributed to numerous pharmacological activities [25]. Up to now, cytotoxic [26,27], antioxidant [28-31], immune enhancement [32, 33], gastroprotective, hepatoprotective [34,35], antitussive [36], hypolipidemic, and cardioprotective effects [37-39], increased milk production [40], hypoglycemic [41], hypotensive [42], and antimicrobial $[43,44]$ effects have been demonstrated. In addition, beneficial effects of $N$. Sativa and thymoquinone on convulsions [45,46], depression [47], men's infertility [48], memory improvement [49], nociception, and inflammation [50,51] have been discussed.

\section{Antinociceptive activity}

Early work by Abdel-Fattah and coworkers demonstrated that oral administration of $\mathrm{N}$. sativa oil (50-400 mg/kg) dose-dependently attenuated the nociceptive responses caused by the acute nociceptive stimuli such as the hot-plate test (thermal stimulus), tail-pinch test (mechanical stimulus), and the early phase of the formalin test (chemical stimulus). It also suppressed inflammatory nociception induced by acetic acid writhing without affecting spontaneous motor activity in mice. In that study, the systemic administration (2.5-10 mg/kg, p.o. and $1-6 \mathrm{mg} / \mathrm{kg}$, i.p.) and the intracerebroventricular (i.c. v.) injection (1-4 mg/kg) of thymoquinone to mice attenuated the response in not only the early phase, but also the late phase of the formalin test. The authors suggested that $N$. sativa oil and TQ produce antinociceptive effects through indirect activation of the supraspinal $\mu$ - 1 and $\kappa$ opioid, but not the $\delta$-opioid receptor subtypes. However, none of these receptor subtypes was implicated in the antinociceptive effect of TQ in the late phase of the formalin test [52].

In addition, Al Nagger et al. studied the neuropharmacological activity of $N$. sativa extracts. Aqueous and methanolic extracts of black cumin were found to elicit thermal and mechanical anti-hyperalgesic effects in the hot-plate and Randall-Selitto tests, respectively [53]. In another study, the aqueous extract of $N$. sativa (500 mg/kg, p.o.) significantly increased the hot plate reaction time in mice [54]. In an investigation by De Sousa and coworkers, thymoquinone and its para-benzoquinone analogues showed a significant reduction in the paw licking time of animals in two phases of the formalin test [55]. In a recent randomized control trial study on mice (30 animals in each group), the ethanolic extract of $N$. sativa showed antinociceptive effects against an acetic acid-induced writhing test [56].

Neurotransmitters, such as gamma aminobutyric acid (GABA), have an important role in descending inhibitory pathways of pain $[57,58]$. An increase in GABAergic tone has been demonstrated in the anxiolytic and anticonvulsant activities of extracts as well as TQ $[45,59,60]$.

Another potential antinociceptive effect of thymoquinone might be through intervening in the serotonin/5-hydroxytriptamine (5HT) pathway. The role of 5-HT and norepinephrine via descending inhibitory pathways has also been demonstrated in the modulation of pain $[61,62]$. Fixed oil of $N$. sativa $(0.1 \mathrm{~mL} / \mathrm{kg} /$ day $)$ for four weeks elicited antidepressant activity through the increased brain 5-HT levels and decreased 5-HT turnover [47].

\section{Anti-inflammatory activity}

The volatile oil $(0.66 \mathrm{ml}$ and $1.55 \mathrm{~mL} / \mathrm{kg}$, i. p.) of $N$. sativa and thymoquinone $(0.5,1.0,5 \mathrm{mg} / \mathrm{kg}$, i.p.) exhibited a dose-dependent anti-inflammatory effect against carrageenan-induced rat hind paw edema and cotton seed pellet granuloma comparable to the reference drug indomethacin (3 $\mathrm{mg} / \mathrm{kg}$, i.p.) [63]. Similarly, AlGhamdi and coworkers demonstrated that the aqueous extract of $N$. sativa possesses an anti-inflammatory action in carrageenan-induced paw edema similar to $100 \mathrm{mg} / \mathrm{kg}$ aspirin; however, it had no antipyretic activity on yeast-induced pyrexia [54]. In another study by Hajhashemi et al. as well as Ghannadi et al., both oral and intraperitoneal administration of polyphenols extracted from $N$. sativa as well as essential oil (200, 400, and $800 \mu \mathrm{L} / \mathrm{kg}$ ) containing $p$-cymene $(37.3 \%)$ and thymoquinone (13.7\%) suppressed the early and late phases of the formalin test, acetic acid-induced writhing in mice, carrageenan-induced paw edema, and croton oil-induced ear edema in rats. The authors reported that treatment with naloxone failed to reverse the analgesic activities of both the polyphenols and essential oil [50,64]. The methanolic extracts of different germination phases of $N$. sativa showed significant anti-inflammatory and antinociceptive effects in kaolin-induced rat paw edema and hot-plate tests, respectively, throughout the duration of the study $(1,3,6$, and $18 \mathrm{~h}$ after the injection of kaolin). The highest effect was observed from the 5th day to the 11th day of germination [65].

- Table 2 summarizes studies investigating the antinociceptive and anti-inflammatory effects of $N$. sativa and its main active constituent TQ in different experimental models.

\section{Potential antioxidant and anti-inflammatory \\ mechanisms according to in vitro studies}

Numerous molecular targets are involved in the antioxidant and anti-inflammatory activities of $N$. sativa and its active agents. As reported by Singh et al., essential oil and oleoresins obtained from black cumin seeds showed antioxidant effects with chelating activity on ferrous ions, a scavenging effect on 1,1-diphenyl2-picrylhydrazyl (DPPH) radical, and activity for the linseed oil system. Meanwhile, such effects by essential oils were higher than that observed by synthetic antioxidants such as buthylhydroxytoluene (BHT) and buthylhydroxyanisole (BHA) [19]. Both the crude fixed oil of $N$. sativa and TQ dose-dependently attenuated thromboxane B2 as well as leukotrienes (LT) B4 and C4 in rat peritoneal leukocytes stimulated with calcium ionophore A23187. Consequently, they can inhibit the cyclooxygenase (COX) and 5-lipoxygenase (5-LPO) pathways of arachidonate metabolism, respectively [66]. The inhibitory effect of fixed oil on leukotriene generation and lipid peroxidation was greater than that of thymoquinone. It seems that other ingredients, such as unsaturated fatty acids, may also contribute to these protective effects. Both compounds also inhibited nonenzymatic peroxidation of brain phospholipid liposomes. In this pathway, the potency of TQ was about ten times more than that of oil. Similarly, 
Table 2 Selected studies showing the different doses and routes of administration of $N$. sativa seed components tested in experimental models of nociception and inflammation.

\begin{tabular}{|c|c|c|c|c|c|}
\hline Compound & Dose & Route & Effect & Animal & Ref. \\
\hline \multirow[t]{2}{*}{ Volatile oil } & 0.66 and $1.55 \mathrm{~mL} / \mathrm{kg}$ & i.p. & Decreased carrageenan-induced hind paws edema & Rat & [63] \\
\hline & & & Decreased cotton seed pellet granuloma & & \\
\hline Thymoquinone & $0.5,1.0,5 \mathrm{mg} / \mathrm{kg}$ & & & & \\
\hline \multirow[t]{4}{*}{ Fixed oil } & $50-400 \mathrm{mg} / \mathrm{kg}$ & oral & Increased animal reaction time to hot plate & Mice & [52] \\
\hline & & & Increased animal reaction time in tail-pinch test & & \\
\hline & & & Inhibited acetic acid-induced writhing & & \\
\hline & & & Inhibited pain response in the first phase of formalin test & & \\
\hline \multirow[t]{5}{*}{ Thymoquinone } & $2.5-10 \mathrm{mg} / \mathrm{kg}$ & oral & Increased animal reaction time to hot plate & Mice & [52] \\
\hline & & & Increased animal reaction time in tail-pinch test & & \\
\hline & & & Inhibited acetic acid-induced writhing & & \\
\hline & $1-6 \mathrm{mg} / \mathrm{kg}$ & i.p. & $\begin{array}{l}\text { Inhibited pain response in both first and second phases of } \\
\text { formalin test }\end{array}$ & & \\
\hline & $1-4 \mu \mathrm{g} /$ mouse & i.c.v & & & \\
\hline \multirow[t]{2}{*}{ Aqueous extract } & $500 \mathrm{mg} / \mathrm{kg}$ & oral & Increased animal reaction time to hot plate & Rats & [54] \\
\hline & & & Decreased carrageenan-induced paw edema & & \\
\hline \multirow{2}{*}{$\begin{array}{l}\text { Aqueous and methanolic } \\
\text { extracts }\end{array}$} & $1.25 \mathrm{~g} / \mathrm{kg}$ & i.p. & Increased animal reaction time to hot plate & Mice & [53] \\
\hline & & & Increased animal reaction time to Randall-Selitto & & \\
\hline \multirow[t]{4}{*}{ Polyphenols } & 200,400 , and $800 \mu \mathrm{L} / \mathrm{kg}$ & oral & Inhibited the early and late phases of formalin-induced pain & Mice & [64] \\
\hline & & i.p. & & & \\
\hline & 200,400 , and $800 \mu \mathrm{L} / \mathrm{kg}$ & & Inhibited acetic acid-induced writhing & & \\
\hline & & & Inhibited carrageenan-induced paw edema & & \\
\hline \multirow[t]{2}{*}{ Essential oil } & 200,400 , and $800 \mu \mathrm{L} / \mathrm{kg}$ & & Inhibited croton oil-induced ear edema & Rats & [50] \\
\hline & & & $\begin{array}{l}\text { Increased animal reaction time in light tail flick test } \\
\text { (only by essential oil) }\end{array}$ & & \\
\hline Ethanolic extract & $50 \mathrm{mg} / \mathrm{kg}$ & i.p. & Reduced acetic acid-induced writhing & Mice & [56] \\
\hline $\begin{array}{l}\text { Thymoquinone and para- } \\
\text { benzoquinones analogues }\end{array}$ & $10 \mathrm{mg} / \mathrm{kg}$ & i.p. & Inhibited formalin-induced paw edema & Mice & [55] \\
\hline \multirow[t]{2}{*}{ Methanolic extract } & $1 \mathrm{~g} / \mathrm{kg}$ & oral & Reduced kaolin-induced paw edema & Rats & [51] \\
\hline & & & Increased the reaction time on hot plate & & \\
\hline Thymoquinone & $2.5,5 \mathrm{mg} / \mathrm{kg}$ & i.p. & Reduced neuropathic pain-induced allodynia and hyperalgesia & Rats & [109] \\
\hline
\end{tabular}

Mansour et al. reported that TQ potently inhibits the formation of leukotrienes in human blood cells by inhibiting both 5-LPO and LTC4 synthase activity [67].

Marsik et al. reported that quinolones from $N$. sativa seeds inhibited COX-1 and 2. The most active ingredient against COX-1 was thymol, while most inhibitory effects on COX-2 were observed with THQ and TQ. Meanwhile, THQ was more specific for COX-2 than TQ [68]. Production of free radical nitric oxide (NO) by the inducible nitric oxide synthase (iNOS) enzyme was dose- and time-dependently inhibited by TQ in the supernatants of LPSstimulated macrophages [69].

In another study by Vaillancourt et al., TQ significantly abolished LPS-induced proinflammatory cytokines such as interleukin1 beta (IL-1 $\beta$ ), tumor necrosis factor-alpha (TNF- $\alpha$ ), metalloproteinase-13 (MMP-13), COX-2, and prostaglandin E2 in an in vitro model of rheumatoid arthritis [70].

There are enough investigations demonstrating that reactive oxygen species (ROS), including NO, which subsequently causes oxidative stress and mediators such as eicosanoids, proinflammatory cytokines, and lytic enzymes released by the inflammatory cells macrophages, microglia, and neutrophils, play an important role in the induction and maintenance of acute or chronic conditions of pain [71-77].

The inhibition of these targets is therefore exploited to attenuate chronic conditions of pain, especially neuropathic pain $[78,79]$. Another potential neuroprotective effect of thymoquinone might be through the activation of PPAR- $\gamma$ (peroxisome proliferator-ac- tivated receptor $\gamma$ ) [80]. The activation of PPAR- $\gamma$ reduces established neuropathic pain in addition to preventing its development [81].

In addition, the phosphorylation of p38 mitogen-activated protein kinases (MAPK), extracellular-regulated kinases, and transcriptional factor, and nuclear factor-kappa B (NF- $k$ B) induced by LPS were also blocked by TQ. The activation of MAPK and nuclear NF- $k$ B has been demonstrated to contribute to chronic pain states such as neuropathic pain [82-84].

\section{Potential antioxidant and anti-inflammatory \\ mechanisms according to in vivo studies}

In line with the in vitro anti-inflammatory effects of $N$. sativa, in vivo studies confirm such effects. Oral administration of TQ and its metabolite dihydrothymoquinone $(25,50$, and $100 \mathrm{mg} / \mathrm{kg}$ for 5 days to mice) showed superoxide anion scavenger activity in different tissues [85]. An anti-inflammatory effect of TQ has been reported in experimental allergic encephalomyelitis (EAE) in an animal model for human multiple sclerosis by increasing the reduced glutathione (GSH) in the spinal cord of animals [86].

Oral administration of TQ ( $80 \mathrm{mg} / \mathrm{kg}$ ) to diabetic rats for 45 days reversed the decreased activities of catalase (CAT), glutathione peroxidase (GPx), and glutathione-S-transferase (GST), and increased antioxidants such as GSH and vitamins C and E, while it attenuated levels of lipid peroxidation markers such as malondialdehyde (MDA) in the kidney and liver tissues of diabetic rats [87]. Similarly, in a study on rabbits, glutamate reductase, GPX, 
and GST activity of the liver were induced by orally administered TQ (10 and $20 \mathrm{mg} / \mathrm{kg} /$ day) for 8 weeks, which could explain the effect of the black seeds in inhibiting the generation of bioactive metabolites known to promote carcinogenesis and oxidative cell damage. However, cytochrome enzymes (CYP1A2 and CYP3A4, but not CYP2E1) were decreased by TQ treatment. Hence, it seems that the potential drug interaction of TQ should be taken into consideration [88]. Ulcerative colitis, a common clinical challenge, is a chronic inflammatory disorder in the gastrointestinal tract with unknown etiology. In a gastric mucosal ischemia/reperfusion $(\mathrm{I} / \mathrm{R})$ injury model, thymoquinone $(10$ and $20 \mathrm{mg} / \mathrm{kg}$ ) decreased gastric acid secretion, and acid output as well as the gastric mucosal content/activity of lipid peroxide, the proton pump, and myeloperoxidase (MPO) as a biomarker of inflammation along with the ulcer index. In contrast, GSH, total nitric oxide, and superoxide dismutase (SOD) were decreased. Such effects were comparable to that of omeprazole as a reference drug [89]. Moreover, thymoquinone showed protective effects on the dextran sodium sulfate (DSS)-induced colitis with a significant reduction in colonic MPO activity and MDA levels as well as an increase in glutathione levels [90]. According to the work of Mahgoub et al., acetic acid-induced colitis in rats was attenuated by pretreatment with thymoquinone $(10 \mathrm{mg} / \mathrm{kg}$ ) for 3 days with a comparable or even higher effect than sulfasalazine, a known anti-colitis drug. In addition, the activity of MPO, platelet activating factor (PAF), and histamine, mediators of inflammation and anaphylaxis, were decreased. In contrast, content of antioxidant GSH was normalized [91].

However, in an earlier report by Juhás et al., TQ $(0.05 \%)$ had no protective effects against trinitobenzensulfonic acid (TNBS)-induced colitis in mice [92]. In an ointment formulation, the black seeds showed anti-inflammatory effects comparable to commercial products [93].

The exposure of the brains of rats to lead revealed that TQ $(20 \mathrm{mg} / \mathrm{kg}$, oral) for one month was able to ameliorate lead-induced neuronal degeneration through inhibiting the microglial reaction [94].

El-Mahmoudy and coworkers determined that the protective effects of TQ in streptozocine (STZ)-induced diabetic rats is mediated via inhibiting the phosphorylation of MAPK [69]. In an experimental model of romatoid arthritis, the oral administration of $5 \mathrm{mg} / \mathrm{kg} /$ day thymoquinone significantly reduced the serum levels of proinflammatory cytokines, IL- $1 \beta$, and TNF- $\alpha$ as well as bone turnover markers such as alkaline phosphatase and tartrate-resistant acid phosphatase [70]. Similarly, thymoquinone was found to inhibit IL-1 $\beta, 5-\mathrm{LPO}$, LTs B4 and C4, T helper 2 cytokines (IL-4, IL-13, and IL-10), and eosinophils in the bronchoalveolar lavage fluid of ovalbumine-induced allergic asthma in mice [95].

The aqueous extract of $N$. sativa ( $200 \mathrm{mg} / \mathrm{kg}$, oral, for 5 days) and, especially, the protein fraction of it possessed a potent protective effect against tetrachloride carbon (CCL4)-induced hepatotoxicity by a significant reduction of TNF- $\alpha$, IL- $1 \beta$, interferon gamma (IFN- $\gamma$ ), and MDA levels, while it increased GSH content both in serum and liver mice tissues. The ethanolic extract showed a less protective effect in that study [96].

In one mouse model of experimentally induced morphine tolerance and dependence, brain oxidative stress and increased iNOS expression were attenuated by coadministration with thymoquinone in mice. However, a morphine-induced progressive increase in the brain glutamate level was not inhibited by this compound [97]. Similarly, Gilhota et al. reported that thymoquinone $(20 \mathrm{mg} /$ $\mathrm{kg}$ ) significantly attenuated the immobilization-induced increase in plasma NO levels of stressed mice [60]. Thymoquinone and black cumin seed oil protected against the lipid peroxidation level after global cerebral ischemia-reperfusion injury in the hippocampus of rats [98]. In a recent work, $N$. sativa oil protection against thioacetamide-induced liver injury was the result of scavenging the free radicals and protecting the liver cells against oxidative damage [99].

In a stroke mode of rats, chloroform and petroleum ether extracts, and aqueous and hydroalcoholic extracts of $N$. sativa ( $400 \mathrm{mg} / \mathrm{kg}$, orally) for 7 days protected animals against focal cerebral ischemia via a decrease in the concentration of thiobarbituric acid reactive substance (TBARS) as well as via an increase in the levels of GSH and antioxidant enzymes such as SOD and CAT $[100,101]$.

$N$. sativa and thymoquinone suppressed COX-2 and oxidative stress markers by decreasing the levels of lipid peroxidation MDA and increasing the level of SOD antioxidant enzyme in pancreatic tissue of STZ-induced diabetic rats [102].

Dariani and colleagues showed that the oral administration of thymoquinone $(10 \mathrm{mg} / \mathrm{kg})$ attenuated seizure activity induced by an intrahippocampal kainite model of temporal lobe epilepsy in rats. Lipid peroxidation was attenuated by decreasing MDA, nitrite, and nitrate levels. Thymoquinone also lowered hippocampal neuronal loss and mitigated astrogliosis [103].

In a model of vancomycin-induced nephrotoxicity in rats, thymoquinone $(10 \mathrm{mg} / \mathrm{kg}$, i.p.) for 8 days decreased kidney levels of MDA; in contrast, it increased activities of SOD and GSH-Px [104]. In addition, neuroprotective effects of thymoquinone have been shown in the 6-hydroxydopamine-induced parkinsonism model via decreasing the MDA and nitrite levels as well as increasing the activity of SOD in the midbrain homogenate of rats [105].

Thymoquinone alleviated serum lipase, amylase, capase-1, and MPO activity as well as proinflammatory cytokines (IL-1beta and IL-18) in rats receiving ethanol and a high-fat diet. An optimum protective effect was obtained with $100 \mathrm{mg} / \mathrm{kg}$ of thymoquinone [106].

Hepatic fibrosis was prevented by oral gavage of thymoquinone $(20 \mathrm{mg} / \mathrm{kg}$ or $40 \mathrm{mg} / \mathrm{kg}$ ) through the regulation of phosphorylation of monophosphate-activated protein kinase (AMPK), liver kinase $\mathrm{B}$, and the inhibition of proinflammatory cytokines. The expression of toll-like receptor 4 (TLR4) was also decreased by thymoquinone [107]. Activation of this receptor has an important role in inflammatory as well as neuropathic pain conditions. After nerve injury, the activation of such a receptor induces microglia and astrocytes as well as the production of the proinflammatory cytokines in the spinal cord, leading to the development and maintenance of inflammatory or neuropathic pain [108].

In a recent work, we examined the effects of thymoquinone on the pain behavioral parameters in rats subjected to chronic constriction injury (CCI) of the left sciatic nerve as a neuropathic pain model [109]. Anti-allodynia and anti-hyperalgesia effects observed with thymoquinone $(2.5 \mathrm{and} 5 \mathrm{mg} / \mathrm{kg}$, i. p.) were still evident after 2 weeks of treatment, which is in agreement with those studies who suggest that the opioid system might have a limited role in the antinociceptive effects of thymoquinone in this model of neuropathic pain $[52,64]$. We showed that antinociceptive effects of thymoquinone might be attributed, in part, to antioxidant activity, microglia activity inhibition, and a reduction in the extent of apoptosis.

According to the Sethi et al. study, it is quite likely that many antiinflammatory activities assigned to $N$. sativa and its main constit- 


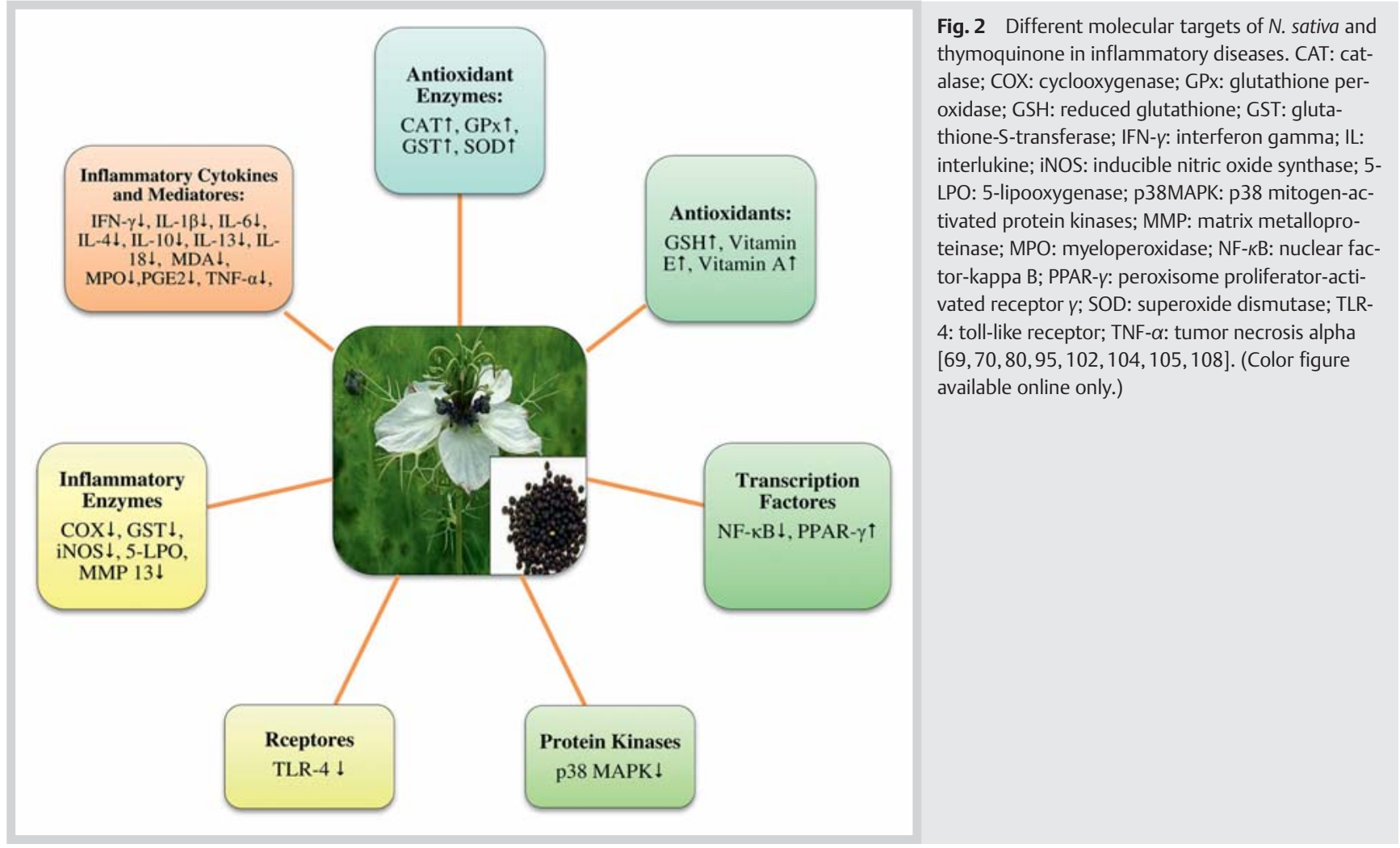

uent thymoquinone, including the effects on enzymes COX, iNOS, and 5-LPO as well as proinflammatory cytokines such as TNF- $\alpha$, IL-1, and IL-6, may be mediated, in part, through the suppression of NF- $k$ B activation [110]. The expression of genes of many enzymes and cytokines are regulated by this transcription factor [111]. The various molecular targets modulated by $N$. Sativa and its major component thymoquinone are depicted in $\bullet$ Fig. 2 [69, $70,80,95,102,104,105,108]$.

\section{Safety and Potential Toxicity}

$\nabla$

There are some studies suggesting that the therapeutic doses of $N$. sativa and thymoquinone have low toxicity and a wide margin of safety. Intraperitoneal administration of $N$. sativa $(50 \mathrm{mg} / \mathrm{kg}$ ) for 5 days did not change the levels of enzymes and metabolites in the liver and kidney of rats [23]. Zaoui et al. investigated the acute and chronic toxicity of $N$. sativa fixed oil. Lethal dose $50 \%$ $\left(\mathrm{LD}_{50}\right)$ values obtained by single doses (acute study) were determined to be $28.8 \mathrm{~mL} / \mathrm{kg}$ and $2.06 \mathrm{~mL} / \mathrm{kg}$ after oral and intraperitoneal administration, respectively, in mice. In chronic toxicity, rats were treated daily with an oral dose of $2 \mathrm{~mL} / \mathrm{kg}$ for 12 weeks. No changes were observed in the key hepatic enzymes levels, including aspartate-aminotransferase, alanine-aminotranferase, gamma-glutamyltransferase, and histopathological modifications in the heart, liver, kidneys, and pancreas after 12 weeks of treatment. The serum cholesterol, triglyceride, and glucose levels as well as the count of leukocytes and platelets decreased significantly compared to the control animals. In contrast, hematocrit and hemoglobin levels increased [112].

In another study, feeding Hibro broiler chicks with a diet containing 20 or $100 \mathrm{~g} / \mathrm{kg}$ of $N$. sativa ground seeds for 7 weeks did not adversely affect the animals' growth [113].
In an investigation using Sprague Dawley rats, the fixed oil of black seed (4.0\%) and the essential oil ( $0.30 \%)$ were safe, as serological factors such as liver and kidney functioning tests, serum protein profile, cardiac enzymes as well as electrolyte balance remained within normal values after 56 days. Similarly, indices of red and white blood cells showed no significant variation. However, rats treated with the fixed oil moiety gained less weight compared to the control, suggesting that black seeds could have beneficial effects in obesity-related disorders [114].

In another study on mice, the $\mathrm{LD}_{50}$ of thymoquinone was $104.7 \mathrm{mg} / \mathrm{kg}$ and $870.9 \mathrm{mg} / \mathrm{kg}$ after oral and intraperitoneal administrations, respectively, whereas the $\mathrm{LD}_{50}$ in rats was determined to be $57.5 \mathrm{mg} / \mathrm{kg}$ and $794.3 \mathrm{mg} / \mathrm{kg}$ after oral and intraperitoneal administration, respectively [115]. As reported by Mansour et al., thymoquinone was effective against CCl4-induced hepatic damage only at a dose of $12.5 \mathrm{mg} / \mathrm{kg}$, but not the higher doses ( 25 and $50 \mathrm{mg} / \mathrm{kg}$ ). It might be hypothesized that TQ at the higher doses induces oxidative stress [116]. In a phase I clinical study conducted on adult patients with advanced malignant cancers and treated with thymoquinone, oral doses of thymoquinone were tolerable for patients up to $2600 \mathrm{mg} /$ day [117]. In a recent study conducted by Tubesha and coworkeres on Sprague Dawley rats, animals treated with $20 \mathrm{ml}$ of thymoquinone-rich fraction nanoemulsion (containing $44.5 \mathrm{mg} / \mathrm{kg} \mathrm{TQ}$ ) appeared normal and there was no mortality or any signs of organ toxicity during the 14-day experimental period [118]. Although, the oil of $N$. sativa was marketed to treat disorders of skin such as acne and eczema [119], two cases of allergic contact dermatitis were reported after topical application of the oil in two persons who suffered from maculopapular eczema $[120,121]$. 


\section{Conclusion}

$\nabla$

$N$. sativa seeds contain a complex of more than 100 compounds, some of which have not yet been studied or even identified. Unsaturated fatty acids in fixed oil and essential oil components, especially thymoquinone, dithymoquinone, thymohydroquinone, thymol, alkaloids, saponins, and vitamins as well as trace elements contribute to its health benefits associated with black cumin seeds. The original research articles published so far have shown the antinociceptive and anti-inflammatory potential of $N$. sativa seeds active ingredients, in particular, thymoquinone, the main active constituent. Although the safety of $N$. sativa oil and its active constituents has been investigated in some studies, data on the bioavailability and other pharmacokinetic parameters of this magic spice are still incomplete.

Furthermore, broad spectrum studies on specific cellular and molecular mechanisms of action as well as controlled clinical trials to prove its efficacy in humans are really needed to further assess the application of $N$. sativa and/or thymoquinone as an antinociceptive agent.

\section{Conflict of Interest}

$\nabla$

The authors declare that there are no conflicts of interest.

\section{References}

1 Datner AM. From medical herbalism to phytotherapy in dermatology: back to the future. Dermatol Ther 2003; 16: 106-113

2 Mahfouz M, El-Dakhakhany M. The isolation of a crystalline active principle from Nigella sativa L. seeds. J Pharm Sci 1960; 1: 1-19

3 Latiff LA, Parhizkar S, Dollah MA, Hassan ST. Alternative supplement for enhancement of reproductive health and metabolic profile among perimenopausal women: a novel role of Nigella sativa. Iran J Basic Med Sci 2014; 17: 980-985

4 Kaatabi H, Bamosa AO, Badar A, Al-Elq A, Abou-Hozaifa B, Lebda F, AlKhadra A, Al-Almaie S. Nigella sativa improves glycemic control and ameliorates oxidative stress in patients with type 2 diabetes mellitus: placebo controlled participant blinded clinical trial. PLoS One 2015; 10: e0113486

5 Khader M, Eckl PM. Thymoquinone: an emerging natural drug with a wide range of medical applications. Iran J Basic Med Sci 2014; 17 : 950-957

6 Ramadan MF. Nutritional value, functional properties and nutraceutical applications of black cumin (Nigella sativa L.): an overview. Int J Food Sci Technol 2007; 42: 1208-1218

7 Al-Jassir MS. Chemical composition and microflora of black cumin ( $\mathrm{Ni}-$ gella sativa L.) seeds growing in Saudi Arabia. Food Chem 1992; 45: 239-242

$8 \mathrm{Kamal} \mathrm{A,} \mathrm{ArifJM,} \mathrm{Ahmad} \mathrm{IZ.} \mathrm{Potential} \mathrm{of} \mathrm{Nigella} \mathrm{sativa} \mathrm{L.} \mathrm{seed} \mathrm{during} \mathrm{dif-}$ ferent phases of germination on inhibition of bacterial growth. E3 J Biotech Pharm Res 2010; 1: 9-13

9 Cheikh-Rouhou S, Besbes S, Hentati B, Blecker C, Deroanne C, Attia H. Nigella sative L., chemical composition and physicochemical charachteristics of lipid fraction. Food Chem 2007; 101: 673-681

10 Hadad GM, Salam RA, Soliman RM, Mesbah MK. High-performance liquid chromatography quantification of principal antioxidants in black seed (Nigella sativa L.) phytopharmaceuticals. J AOAC Int 2012; 95: 1043-1047

11 Al-Saleh IA, Billedo G, El-Doush II. Levels of selenium, dl- $\alpha$-tocopherol, $\mathrm{dl}-\gamma$-tocopherol, all-trans-retinol, thymoquinone and thymol in different brands of Nigella sativa seeds. J Food Compost Anal 2006; 19: 167175

12 Muhammad TS. Characterization of black cumin seed oil and exploring its role as a functional food. Faisalabad: University of Agriculture; 2009

13 Gad AM, El-Dakhakhany M, Hassan MM. Studies on the chemical constitution of Egyptian Nigella sativa L. oil. Planta Med 1963; 11: 134138
14 Atta UR, Malik S, Hasan SS, Choudhary MI, Chao-Zhou N, Clardy J. Nigellidine, a new indazole alkaloid from seeds of Nigella sativa. Tetrahedron Lett 1995; 36: 1993-1996

15 Sultan MT, Butt MS, Anjum FM, Jamil A, Akhtar S, Nasir M. Nutritional profile of indigenous cultivar of black cumin seeds and antioxidant potential of its fixed and essential oil. Pak J Bot 2009; 41: 1321-1330

16 El-Tahir Kamal EH, Bakeet DM. The Black seed Nigella sativa Linnaeus a mine for multi cures: a plea for urgent clinical evaluation of its volatile oil. J T U Med Sci 2006; 1: 1-19

17 Ansari AA, Hassan S, Kenne L, Wehler T. Structural studies on a saponin isolated from Nigella sativa. Phytochemistry 1988; 27: 3977-3979

18 Burits $M$, Bucar F. Antioxidant activity of Nigella sativa essential oil. Phytother Res 2000; 14: 323-328

19 Singh S, Das SS, Singh G, Schuff C, de Lampasona MP, Catalan CA. Composition, in vitro antioxidant and antimicrobial activities of essential oil and oleoresins obtained from black cumin seeds (Nigella sativa L.). Biomed Res Int 2014; 2014: 10

20 Ghosheh OA, Houdi AA, Crooks PA. High performance liquid chromatographic analysis of the pharmacologically active quinones and related compounds in the oil of the black seed (Nigella sativa L.). J Pharm Biomed Anal 1999; 19: 757-762

21 Woo CC, Kumar AP, Sethi G, Tan KH. Thymoquinone: potential cure for inflammatory disorders and cancer. Biochem Pharmacol 2012; 83: 443-451

22 Heiss AG, Stika HP, De Zorzi N, Jursa M. Nigella in the mirror of time a brief attempt to draw a genus' ethnohistorical portrait. Offa 2012; 69/ 70: $147-169$

23 Junemann M, Luetjohann S. Three great healing herbs: tea tree, St. Johns wort, and black cumin. Twin Lakes, WI: Lotus Light Publications; 1998: 91-116

24 Nergiz C, Ötleș S. Chemical composition of Nigella sativa L. seeds. Food Chem 1993; 48: 259-261

25 Ziaei T, Moharreri N, Hosseinzadeh $H$. Review of pharmacological and toxicological effects of Nigella sativa and its active constituents. J Med Plants 2012; 11: 16-42

26 Ali BH, Blunden G. Pharmacological and toxicological properties of $\mathrm{Ni}-$ gella sativa. Phytother Res 2003; 17: 299-305

27 El Daly ES. Protective effect of cysteine and vitamin E, Crocus sativus and Nigella sativa extracts on cisplatin-induced toxicity in rats. J Pharm Belg 1998; 53: 87-93

28 Cikman O, Ozkan A, Aras AB, Soylemez O, Alkis H, Taysi S, Karaayvaz M. Radioprotective effects of Nigella Sativa oil against oxidative stress in liver tissue of rats exposed to total head irradiation. J Invest Surg 2014: 5: 262-266

29 Burits M, Bucar F. Antioxidant activity of Nigella sativa essential oil. Phytother Res 2000; 14: 323-328

30 Mousavi S, Tayarani-Najaran Z, Asghari M, Sadeghnia H. Protective effect of Nigella sativa extract and thymoquinone on serum/glucose deprivation-induced PC12 cells death. Cell Mol Neurobiol 2010; 30: 591598

31 Ragheb A, Attia A, Eldin WS, Elbarbry F, Gazarin S, Shoker A. The protective effect of thymoquinone, an anti-oxidant and anti-inflammatory agent, against renal injury: a review. Saudi J Kidney Dis Transpl 2009; 20: 741-752

32 Awad E, Austin D, Lyndon AR. Effect of black cumin seed oil (Nigella sativa) and nettle extract (Quercetin) on enhancement of immunity in rainbow trout, Oncorhynchus mykiss (Walbaum). Aquaculture 2013; 388-391: 193-197

33 Assayed ME. Radioprotective effects of black seed (Nigella sativa) oil against hemopoietic damage and immunosuppression in gamma-irradiated rats. Immunopharmacol Immunotoxicol 2010; 32: 284-296

34 Abdel-Sater KA. Gastroprotective effects of Nigella Sativa oil on the formation of stress gastritis in hypothyroidal rats. Int J Physiol Pathophysiol Pharmacol 2009; 1: 143-149

35 Mahmoud MR, El-Abhar HS, Saleh S. The effect of Nigella sativa oil against the liver damage induced by Schistosoma mansoni infection in mice. J Ethnopharmacol 2002; 79: 1-11

36 Hosseinzadeh $H$, Eskandari M, Ziaee T. Antitussive effect of thymoquinone, a constituent of Nigella Sativa seeds, in guinea pigs. Pharmacologyonline 2008; $2:$ 480-484

37 Ibrahim RM, Hamdan NS, Mahmud R, Imam MU, Saini SM, Rashid SN, Abd Ghafar SA, Latiff LA, Ismail M. A randomised controlled trial on hypolipidemic effects of Nigella Sativa seeds powder in menopausal women. J Transl Med 2014; 12: 82 
38 Ebru U, Burak U, Yusuf S, Reyhan B, Arif K, Faruk TH, Emin M, Aydin K, Atilla II, Semsettin S, Kemal E. Cardioprotective effects of Nigella sativa oil on cyclosporine A-induced cardiotoxicity in rats. Basic Clin Pharmacol Toxicol 2008; 103: 574-580

39 Nagi MN, Mansour MA. Protective effect of thymoquinone against doxorubicin-induced cardiotoxicity in rats: a possible mechanism of protection. Pharmacol Res 2000; 41: 283-289

40 Hosseinzadeh H, Tafaghodi M, Mosavi MJ, Taghiabadi E. Effect of aqueous and ethanolic extracts of Nigella sativa seeds on milk production in rats. J Acupunct Meridian Stud 2013; 6: 18-23

41 Meddah B, Ducroc R, El Abbes Faouzi M, Eto B, Mahraoui L, BenhaddouAndaloussi A, Martineau LC, Cherrah Y, Haddad PS. Nigella sativa inhibits intestinal glucose absorption and improves glucose tolerance in rats. J Ethnopharmacol 2009; 121: 419-424

42 Zaoui A, Cherrah Y, Lacaille-Dubois MA, Settaf A, Amarouch H, Hassar M. Diuretic and hypotensive effects of Nigella sativa in the spontaneously hypertensive rat. Therapie 2000; 55: 379-382

43 Hanafy MS, Hatem ME. Studies on the antimicrobial activity of Nigella sativa seed (black cumin). J Ethnopharmacol 1991; 34: 275-278

44 Dey D, Ray R, Hazra B. Antitubercular and antibacterial activity of quinonoid natural products against multi-drug resistant clinical isolates. Phytother Res 2014; 28: 1014-1021

45 Hosseinzadeh H, Parvardeh S, Nassiri-Asl M, Mansouri MT. Intracerebroventricular administration of thymoquinone, the major constituent of Nigella sativa seeds, suppresses epileptic seizures in rats. Med Sci Monit 2005; 11: BR106-BR110

46 Damião PD, Franklin FFN, Camila CMPS, Rubens BB, Ygor WV, Marciana $P U$, Timothy JB, Reinaldo ND. Anticonvulsant activity of thymoquinone and its structural analogues. Rev Bras Farmacogn 2011; 21: 427-433

47 Perveen T, Haider S, Zuberi NA, Saleem S, Sadaf S, Batool Z. Increased 5HT levels following repeated administration of Nigella sativa L. (black seed) oil produce antidepressant effects in rats. Sci Pharm 2014; 82: 161-170

48 Kolahdooz M, Nasri S, Modarres SZ, Kianbakht S, Huseini HF. Effects of Nigella sativa L. seed oil on abnormal semen quality in infertile men: a randomized, double-blind, placebo-controlled clinical trial. Phytomedicine 2014; 21: 901-905

49 Hosseini M, Mohammadpour T, Karami R, Rajaei Z, Sadeghnia HR, Soukhtanloo M. Effects of the hydro-alcoholic extract of Nigella sativa on scopolamine-induced spatial memory impairment in rats and its possible mechanism. Chin J Integr Med 2015; 21: 438-444

50 Ghannadi A, Hajhashemi V, Jafarabadi H. An investigation of the analgesic and anti-inflammatory effects of Nigella sativa seed polyphenols. J Med Food 2005; 8: 488-493

51 Islam MH, Ahmad IZ, Salman MT. In vivo evaluation of anti-inflammatory and analgesic activies of Nigella sativa seed during germination. Int J Pharm Pharm Sci 2013; 5: 451-454

52 Abdel-Fattah AM, Matsumoto $K$, Watanabe $H$. Antinociceptive effects of Nigella sativa oil and its major component, thymoquinone, in mice. Eur J Pharmacol 2000; 400: 89-97

53 Al-Naggar TB, Gomez-Serranillos MP, Carretero ME, Villar AM. Neuropharmacological activity of Nigella sativa L. extracts. J Ethnopharmacol 2003; 88: 63-68

54 Al-Ghamdi MS. The anti-inflammatory, analgesic and antipyretic activity of Nigella sativa. J Ethnopharmacol 2001; 76: 45-48

55 De Sousa DP, Nóbrega FF, Santos CC, Benedito RB, Vieira YW, Uliana MP, Brocksom TJ, de Almeida RN. Antinociceptive activity of thymoquinone and its structural analogues: a structure-activity relationship study. Trop J Pharm Res 2012; 11: 605-610

56 Bashir MU, Qureshi HJ. Analgesic effect of Nigella sativa seeds extract on experimentally induced pain in albino mice. J Coll Physicians Surg Pak 2010; 20: 464-467

57 Dickenson AH, Chapman V, Green GM. The pharmacology of excitatory and inhibitory amino acid-mediated events in the transmission and modulation of pain in the spinal cord. Gen Pharmacol 1997; 28: 633638

58 Enna SJ, McCarson KE. The role of GABA in the mediation and perception of pain. Adv Pharmacol 2006; 54: 1-27

59 El-Naggar T, Gómez-Serranillos MP, Palomino OM, Arce C, Carretero ME. Nigella sativa L. seed extract modulates the neurotransmitter amino acids release in cultured neurons in vitro. J Biomed Biotechnol 2010; 2010: 398312

60 Gilhotra N, Dhingra $D$. Thymoquinone produced antianxiety-like effects in mice through modulation of GABA and NO levels. Pharmacol Rep 2011; 63: 660-669
61 Marks DM, Shah MJ, Patkar AA, Masand PS, Park GY, Pae CU. Serotoninnorepinephrine reuptake inhibitors for pain control: premise and promise. Curr Neuropharmacol 2009; 7: 331-336

62 Lee YC, Chen PP. A review of SSRIs and SNRIs in neuropathic pain. Expert Opin Pharmacother 2010; 11: 2813-2825

63 Mutabagani A, El-Mahdy SAM. A study of the anti-inflammatory activity of Nigella sativa L. and thymoquinone in rats. Saudi Pharm J 1997; 5: $110-113$

64 Hajhashemi V, Ghannadi A, Jafarabadi H. Black cumin seed essential oil as a potent analgesic and antiinflammatory drug. Phytother Res 2004; 18: 195-199

65 Kamal A, Arif JM, Ahmad IZ. Potential of Nigella sativa L. seed during different phases of germination on inhibition of bacterial growth. J Biotech Pharm Res 2010; 1: 9-13

66 Houghton PJ, Zarka R, de las Heras B, Hoult JR. Fixed oil of Nigella sativa and derived thymoquinone inhibit eicosanoid generation in leukocytes and membrane lipid peroxidation. Planta Med 1995; 61: 33-36

67 Mansour M, Tornhamre S. Inhibition of 5-lipoxygenase and leukotriene C4 synthase in human blood cells by thymoquinone. J Enzyme Inhib Med Chem 2004; 19: 431-436

68 Marsik P, Kokoska L, Landa P, Nepovim A, Soudek P, Vanek T. In vitro inhibitory effects of thymol and quinones of Nigella sativa seeds on cyclooxygenase-1-and-2-catalyzed prostaglandin E2 biosyntheses. Planta Med 2005; 71: 739-742

69 El-Mahmoudy A, Matsuyama H, Borgan MA, Shimizu Y, El-Sayed MG Minamoto N, Takewaki T. Thymoquinone suppresses expression of inducible nitric oxide synthase in rat macrophages. Int Immunopharmacol 2002; 2: 1603-1611

70 Vaillancourt F, Silva P, Shi Q Fahmi H, Fernandes JC, Benderdour M. Elucidation of molecular mechanisms underlying the protective effects of thymoquinone against rheumatoid arthritis. J Cell Biochem 2011; 112: 107-117

71 Moalem G, Tracey DJ. Immune and inflammatory mechanisms in neuropathic pain. Brain Res Rev 2006; 51: 240-264

72 Sliva J, Prochazkova M, Dolezal T. The role of cyclooxygenase in pain processing in CNS. Cesk Fysiol 2004; 53: 176-180

73 Chung JM. The role of reactive oxygen species (ROS) in persistent pain Mol Interv 2004; 4: 248-250

74 Berger JV, Deumens R, Goursaud S, Schafer S, Lavand'homme P, Joosten $E A$, Hermans $E$. Enhanced neuroinflammation and pain hypersensitivity after peripheral nerve injury in rats expressing mutated superoxide dismutase 1. J Neuroinflammation 2011; 8: 33

75 Amor S, Puentes F, Baker D, van der Valk P. Inflammation in neurodegenerative diseases. Immunology 2010; 129: 154-169

76 Noguchi K, Okubo M. Leukotrienes in nociceptive pathway and neuropathic/inflammatory pain. Biol Pharm Bull 2011; 34: 1163-1169

77 Vallejo R, Tilley DM, Vogel L, Benyamin R. The role of glia and the immune system in the development and maintenance of neuropathic pain. Pain Pract 2010; 10: 167-184

78 Zhu X, Li Q Chang R, Yang D, Song Z, Guo Q, Huang C. Curcumin alleviates neuropathic pain by inhibiting $\mathrm{p} 300 / \mathrm{CBP}$ histone acetyltransferase activity-regulated expression of BDNF and cox-2 in a rat model. PLoS One 2014; 9: e91303

79 Ko YK, Youn AM, Hong BH, Kim YH, Shin YS, Kang PS, Yoon KJ, Lee WH. Antinociceptive effect of phenyl N-tert-butylnitrone, a free radical scavenger, on the rat formalin test. Korean J Anesthesiol 2012; 62: 558-564

80 Woo CC, Loo SY, Gee V, Yap CW, Sethi G, Kumar AP, Tan KH. Anticancer activity of thymoquinone in breast cancer cells: possible involvement of PPAR- $\gamma$ pathway. Biochem Pharmacol 2011; 82: 464-475

81 Griggs RB, Donahue RR, Morgenweck J, Grace PM, Sutton A, Watkins LR, Taylor $B K$. Pioglitazone rapidly reduces neuropathic pain through astrocyte and nongenomic PPAR $\gamma$ mechanisms. Pain 2015; 156: 469-482

82 Jeon Y, Kim CE, Jung D, Kwak K, Park S, Lim D, Kim S, Baek W. Curcumin could prevent the development of chronic neuropathic pain in rats with peripheral nerve injury. Curr Ther Res Clin Exp 2013; 74: 1-4

83 Obata K, Noguchi K. MAPK activation in nociceptive neurons and pain hypersensitivity. Life Sci 2004; 74: 2643-2653

84 Lee MK, Han SR, Park MK, Kim MJ, Bae YC, Kim SK, ParkJS, Ahn DK. Behavioral evidence for the differential regulation of p-p 38 MAPK and p-NFkappaB in rats with trigeminal neuropathic pain. Mol Pain 2011; 7: 57

85 Mansour MA, Nagi MN, El-Khatib AS, Al-Bekairi AM. Effects of thymoquinone on antioxidant enzyme activities, lipid peroxidation and DTdiaphorase in different tissues of mice: a possible mechanism of action. Cell Biochem Funct 2002; 20: 143-151 
86 Mohamed A, Shoker A, Bendjelloul F, Mare A, Alzrigh M, Benghuzzi H, Desin $T$. Improvement of experimental allergic encephalomyelitis (EAE) by thymoquinone; an oxidative stress inhibitor. Biomed Sci Instrum 2003; 39: 440-445

87 Sankaranarayanan C, Pari L. Thymoquinone ameliorates chemical induced oxidative stress and beta-cell damage in experimental hyperglycemic rats. Chem Biol Interact 2011; 190: 148-154

88 Elbarbry F, Ragheb A, Marfleet T, Shoker A. Modulation of hepatic drug metabolizing enzymes by dietary doses of thymoquinone in female New Zealand White rabbits. Phytother Res 2012; 26: 1726-1730

89 Magdy MA, Hanan el-A, Nabila el-M. Thymoquinone: Novel gastroprotective mechanisms. Eur J Pharmacol 2012; 697: 126-131

90 Lei X, Liu M, Yang Z, Ji M, Guo X, Dong W. Thymoquinone prevents and ameliorates dextran sulfate sodium-induced colitis in mice. Dig Dis Sci 2012; 57: 2296-2303

91 Mahgoub AA. Thymoquinone protects against experimental colitis in rats. Toxicol Lett 2003; 143: 133-143

92 Juhas S, Cikos S, Czikkova S, Vesela J, Il'kova G, Hajek T, Domaracka K, Domaracky M, Bujnakova D, Rehak P, Koppel J. Effects of borneol and thymoquinone on TNBS-induced colitis in mice. Folia Biol (Praha) 2008; $54: 1-7$

93 Zedlitz S, Kaufmann R, Boehncke WH. Allergic contact dermatitis from black cumin (Nigella sativa) oil-containing ointment. Contact Dermatitis 2002; 46: 188

94 Radad K, Hassanein K, Al-Shraim M, Moldzio R, Rausch WD. Thymoquinone ameliorates lead-induced brain damage in Sprague Dawley rats. Exp Toxicol Pathol 2014; 66: 13-17

95 El Gazzar M, El Mezayen R, Marecki JC, Nicolls MR, Canastar A, Dreskin $S C$. Anti-inflammatory effect of thymoquinone in a mouse model of allergic lung inflammation. Int Immunopharmacol 2006; 6: 11351142

96 Michel CG, El-Sayed NS, Moustafa SF, Ezzat SM, Nesseem DI, El-Alfy TS. Phytochemical and biological investigation of the extracts of Nigella sativa L. seed waste. Drug Test Anal 2011; 3: 245-254

97 Abdel-Zaher AO, Mostafa MG, Farghly HM, Hamdy MM, Omran GA, AlShaibani NK. Inhibition of brain oxidative stress and inducible nitric oxide synthase expression by thymoquinone attenuates the development of morphine tolerance and dependence in mice. Eur J Pharmacol 2013; 702: 62-70

98 Hosseinzadeh H, Parvardeh S, Asl MN, Sadeghnia HR, Ziaee T. Effect of thymoquinone and Nigella sativa seeds oil on lipid peroxidation level during global cerebral ischemia-reperfusion injury in rat hippocampus. Phytomedicine 2007; 14: 621-627

99 Nehar S, Kumari M. Ameliorating effect of Nigella sativa oil in thioacetamide-induced liver cirrhosis in albino rats. Ind J Pharm Edu Res 2013; 47: 135-139

100 Akhtar M, Maikiyo AM, Najmi AK, Khanam R, Mujeeb M, Aqil M. Neuroprotective effects of chloroform and petroleum ether extracts of $\mathrm{Ni}$ gella sativa seeds in stroke model of rat. J Pharm Bioallied Sci 2013; 5: $119-125$

101 Akhtar M, Maikiyo AM, Khanam R, Mujeeb M, Aqil M, Najmi AK. Ameliorating effects of two extracts of Nigella sativa in middle cerebral artery occluded rat. J Pharm Bioallied Sci 2012; 4: 70-75

102 Al Wafai RJ. Nigella sativa and thymoquinone suppress cyclooxygenase-2 and oxidative stress in pancreatic tissue of streptozotocin-induced diabetic rats. Pancreas 2013; 42: 841-849

103 Dariani S, Baluchnejadmojarad T, Roghani M. Thymoquinone attenuates astrogliosis, neurodegeneration, mossy fiber sprouting, and oxidative stress in a model of temporal lobe epilepsy. J Mol Neurosci 2013; 3: 679-686
104 Basarslan F, Yilmaz N, Ates S, Ozgur T, Tutanc M, Motor VK, Arica V, Yilmaz C, Inci M, Buyukbas S. Protective effects of thymoquinone on vancomycin-induced nephrotoxicity in rats. Hum Exp Toxicol 2012; 31: 726-733

105 Sedaghat R, Roghani M, Khalili M. Neuroprotective effect of thymoquinone, the Nigella sativa bioactive compound, in 6-hydroxydopamineinduced hemi-parkinsonian rat model. Iran J Pharm Res 2014; 13: 227-234

106 Suguna P, Geetha A, Aruna R, Siva GV. Effect of thymoquinone on ethanol and high fat diet induced chronic pancreatitis-a dose response study in rats. Indian J Exp Biol 2013; 51: 292-302

107 Bai T, Yang Y, Wu YL, Jiang S, Lee JJ, Lian LH, Nan JX. Thymoquinone alleviates thioacetamide-induced hepatic fibrosis and inflammation by activating LKB1-AMPK signaling pathway in mice. Int Immunopharmacol 2014; 19: 351-357

108 Qi J, Buzas K, Fan H, Cohen JI, Wang K, Mont E, Klinman D, Oppenheim JJ, Howard OM. Painful pathways induced by TLR stimulation of dorsal root ganglion neurons. J Immunol 2011; 186: 6417-6426

109 Amin B, Taheri Heravi MM, Hosseinzadeh $H$. Effects of intraperitonea thymoquinone on chronic neuropathic pain in rats. Planta Med, advance online publication 1 October 2014; DOI: 10.1055/s-00341383062

110 Sethi G, Ahn KS, Aggarwal BB. Targeting nuclear factor-kappa B activation pathway by thymoquinone: role in suppression of antiapoptotic gene products and enhancement of apoptosis. Mol Cancer Res 2008; 6: 1059-1070

111 Ahn KS, Aggarwal BB. Transcription factor NF-kappaB: a sensor for smoke and stress signals. Ann N Y Acad Sci 2005; 1056: 218-233

112 Zaoui A, Cherrah Y, Mahassini N, Alaoui K, Amarouch H, Hassar M. Acute and chronic toxicity of Nigella sativa fixed oil. Phytomedicine 2002; 9: 69-74

113 Al-Homidan A, Al-Qarawi AA, Al-Waily SA, Adam SE. Response of broiler chicks to dietary Rhazya stricta and Nigella sativa. Br Poult Sci 2002; 43: 291-296

114 Tauseef Sultan M, Butt MS, Anjum FM. Safety assessment of black cumin fixed and essential oil in normal Sprague Dawley rats: serological and hematological indices. Food Chem Toxicol 2009; 47: 2768-2775

115 Al-Ali A, Alkhawajah AA, Randhawa MA, Shaikh NA. Oral and intraperitoneal $\mathrm{LD}_{50}$ of thymoquinone, an active principle of Nigella sativa, in mice and rats. J Ayub Med Coll Abbottabad 2008; 20: 25-27

116 Mansour MA, Ginawi OT, El-Hadiyah T, El-Khatib AS, Al-Shabanah OA, Al-Sawaf HA. Effects of volatile oil constituents of Nigella sativa on carbon tetrachloride-induced hepatotoxicity in mice: evidence for antioxidant effects of thymoquinone. Res Commun Mol Pathol Pharmacol 2001; 110: 239-251

117 Al-Amri AM, Bamosa AO. Phase I safety and clinical activity study of thymoquinone in patients with advanced refractory malignant disease. Shiraz E Med J 2009; 10: 107-111

118 Tubesha Z, Imam MU, Mahmud R, Ismail M. Study on the potential toxicity of a thymoquinone-rich fraction nanoemulsion in Sprague Dawley rats. Molecules 2013; 18: 7460-7472

119 Yousefi M, Barikbin B, Kamalinejad M, Manouchehrian M, Hejazi S. Comparison of therapeutic effect of topical Nigella with betamethasone and eucerin in hand eczema. J Eur Acad Dermatol Venereol 2013; 27: 1498-1504

120 Steinmann A, Schatzle M, Agathos M, Breit R. Allergic contact dermatitis from black cumin (Nigella sativa) oil after topical use. Contact Dermatitis 1997; 36: 268-269

121 Nosbaum A, Ben Said B, Halpern SJ, Nicolas JF, Berard F. Systemic allergic contact dermatitis to black cumin essential oil expressing as generalized erythema multiforme. Eur J Dermatol 2011; 21: 447-448 